\title{
PENINGKATAN HASIL BELAJAR SISWA MENGGUNAKAN PEMBELAJARAN TANDUR BERBANTUAN MEDIA PUZZLE
}

\author{
Mohamad Taufik Evendi ${ }^{1}$, Imanuel Sairo Awang ${ }^{2}, \&$ Markus Iyus Supiandi ${ }^{3}$ \\ ${ }^{1}$ Pendidikan Guru Sekolah Dasar, STKIP Persada Khatulistiwa \\ ${ }^{2}$ Pendidikan Guru Sekolah Dasar, STKIP Persada Khatulistiwa \\ ${ }^{3}$ Pendidikan Biologi, STKIP Persada Khatulistiwa \\ Email: encek3996@gmail.com; iman.saiaw@gmail.com; msupiandi@gmail.com
}

\section{INFO ARTIKEL}

Riwayat Artikel:

Menerima : 02 April 2020

Revisi : 14 April 2020

Diterima : 20 April 2020

\section{Kata Kunci:}

Hasil Belajar, Model

Pembelajaran TANDUR, Media

Puzzle

Keywords:

Learning Outcomes, TANDUR

Learning Model, Media Puzzle

\section{Korespondensi:}

Imanuel Sairo Awang

Pendidikan Guru Sekolah Dasar,

STKIP Persada Khatulistiwa,

Sintang

Email :

iman.saiaw@gmail.com

\section{ABSTRAK}

Penelitian dilatarbelakangi dengan belum optimalnya capaian hasil belajar siswa. Oleh karena itu, penelitian ini bertujuan untuk meningkatkan hasil belajar siswa menggunakan pembelajaran TANDUR berbantuan media puzzle di kelas IV SD Negeri 01 Sintang tahun pelajaran 2019/2020. Penelitian berbentuk penelitian tindakan kelas yang dilaksanakan dalam 2 siklus. Alat pengumpul data yaitu lembar observasi, lembar tes dan angket. Subjek penelitian adalah siswa kelas IV SD Negeri 01 Sintang, sedangkan objek penelitiannya adalah model pembelajaran TANDUR berbantuan media puzzle. Analisis data menggunakan teknik analisis interaktif. Berdasarkan hasil penelitian diperoleh bahwa: (1) hasil observasi keterlaksanaan pembelajaran sebesar $69,05 \%$ pada siklus I dan pada siklus II sebesar 95,46\% berkategori sangat baik; (2) Hasil belajar ranah kognitif dengan nilai rata-rata siklus I sebesar 67,91, sedangkan pada siklus II mengalami peningkatan menjadi 81,04 dengan kategori lulus, dengan ketuntasan sebesar $87,5 \%$ pada siklus II. Pada ranah afektif nilai rata-rata siklus I sebesar 64,17 , sedangkan pada siklus II mengalami peningkatan sebesar 72,92 dengan kategori baik, pada ranah psikomotor nilai rata-rata siklus I sebesar 64,24, sedangkan pada siklus II mengalami peningkatan sebesar 73,96 dengan kategori baik. (3) Peningkatan hasil belajar pada ranah kognitif, afektif, dan psikomotor masingmasing sebesar 13,13; 8,75; dan 9,72. Dengan demikian, dapat disimpulkan bahwa pembelajaran TANDUR berbantuan media puzzle dapat meningkatkan hasil belajar siswa.

\section{ABSTRACT}

The research is motivated by the suboptimal achievement of student learning outcomes. Therefore, this study aims to improve student learning outcomes using TANDUR learning assisted by puzzle media in class IV SD Negeri 01 Sintang in the academic year 2019/2020. The study was conducted in 2 cycles classroom action research. The data collection tools are observation sheets, test sheets and questionnaires. The research subjects were grade IV students at SD Negeri 01 Sintang, while the object of the research was the TANDUR learning model assisted by puzzle media. Data analysis uses interactive analysis techniques. The result shows that: (1) the results of observations of the implementation of learning by $69.05 \%$ in the first cycle and in the second cycle of $95.46 \%$ categorized as very good; (2) Learning outcomes of the cognitive domain with an average value of 67.91 for the first cycle, while in the second cycle increased to 81.04 with the very good category, with completeness of $87.5 \%$ in the second cycle;in the affective domain the average value of the first cycle was 64.17, whereas in the second cycle an increase of 72.92 with a good category. In the psychomotor domain, the average value of cycle I was 64.24, whereas in cycle II it had increased by 73.96 with a good category. (3)Improved learning outcomes in the cognitive, affective, and psychomotor domains respectively 13.13 8.75; and 9.72. Thus, it can be concluded that the TANDUR learning assisted bypuzzle media can improve student learning outcomes. 


\section{PENDAHULUAN}

Hasil belajar adalah perubahanperubahan yang terjadi pada diri siswa baik yang menyangkut aspek afektif, kognitif, dan psikomotorik sebagai hasil dari kegiatan belajar (Susanto, 2013: 5). Pada umumnya hasil belajar dapat dikelompokkan menjadi tiga aspek yaitu: ranah kognitif, ranah afektif, dan ranah psikomotor, dan secara eksplisit ketiga aspek ini tidak dapat dipisahkan satu sama lain (Nurbudiyani, 2013: 89). Apapun jenis mata ajarnya selalu menggunakan tiga aspek tersebut namun memiliki penekanan yang berbeda. Awang (2017: 49) menuliskan, "Ranah kognitif mengacu pada bidang pengetahuan (knowledge). Kemudian ranah afektif mengacu pada bidang rasa (feeling tone), emosi (emotion), dan derajat keberterimaan/penolakan (degree of acceptance or rejection) dan yang terakhir adalah ranah psikomotorik yaitu mengacu pada bidang ketrampilan motorik dan otot."

Ranah kognitif adalah ranah yang mencakup kegiatan mental (otak) seperti kemampuan berpikir, memahami, menghapal, mengaplikasi, menganalisa, mensintesa, dan kemampuan mengevaluasi (Nubudiyani, 2013: 89).Hasil belajar dalam aspek kognitif erat kaitannya dengan bertambahnya wawasan ilmu dan pengetahuan yang dimiliki oleh seseorang (Pribadi, 2014: 94). Seseorang akan memiliki pemahaman yang lebih baik setelah menempuh program pelatihan. Ranah kognitif berkaitan dengan pengetahuan, kemampuan, dan kemahiran intelektual.Ranah kognitif meliputi aspek mengingat, memahami, mengaplikasikan, menganalisis, mengevaluasi, dan mencipta (Anderson dan Krathwohl, 2001: 66-68).

Afektif adalah aspek yang berkaitan dengan sikap dan nilai (value) (Baharuddin, 2004: 102).Sikap adalah salah satu istilah bidang psikologi yang berhubungan dengan persepsi dan tingkah laku.Istilah sikap melibatkan beberapa pengetahuan tentang situasi, namun aspek paling esensial dalam sikap adalah adanya perasaan atau emosi, kecenderungan terhadap perbuatan yang berhubungan dengan pengetahuan. Krathwohl dkk. (Nubudiyani, 2013: 90), mengelompokkan ranah afektif ini menjadi lima jenjang yaitu, a) menerima atau memperhatikan (receiving), b) menanggapi (responding), c) menailai atau menghargai (valuing), d) mengatur atau mengorganisasikan (organization), dan e) karakterisasi dengan suatu nilai atau kelompok nilai (characterization).

Aspek psikomotorik merupakan proses pengetahuan yang banyak didasarkan dari pengembangan proses mental melalui aspekaspek otot dan membentuk keterampilan (Sukardi, 2009: 76-77). Dalam pengembangannya, pendidikan psikomotorik disamping proses menggerakkan otot, juga telah berkembang dengan pengetahuan yang berkaitan dengan keterampilan hidup. Aspek psikomotorik sebagai hasil belajar berhubungan dengan keterampilan fisik yang dimiliki oleh seseorang untuk melakukan suatu tugas atau pekerjaan. Belajar akan membuat seseorang memiliki keterampilan dalam melakukan sesuatu tugas dan pekerjaan yang lebih baik daripada sebelumnya. Aspek psikomotorik erat kaitannya dengan 
kemampuan yang dimiliki seseorang dalam melakukan kegiatan-kegiatan yang bersifat fisik. Aspek psikomotor memiliki empat jenjang kemampuan meliputi imitasi, manipulasi, presisi,dan artikulasi (Pribadi, 2014: 100-101).

Berdasarkan hasil observasi serta wawancara yang telah dilakukan pada tanggal 4 April 2019 dengan guru kelas IV SD Negeri 01 Sintang, menunjukan bahwa siswa kelas IV SD Negeri 01 Sintang hasil belajar dalam tiga ranah yaitu kognitif, afektif, dan psikomotorik masih berkategori kurang memuaskan. Hal ini terlihat dari tiga aspek yaitu kognitif, afektif, dan psikomotor, pada aspek kognitif siswa sulit memahami materi pelajaran yang disampaikan guru, siswa kurang aktif dalam proses pembelajaran, rasa ingin tahu mereka kurang terhadap materi pelajaran, siswa kurang kreatif selama proses pembelajaran, dan siswa tidak mampu menjelaskan apa yang sudah diajarkan oleh guru. Pada aspek afektif siswa kurangnya minat belajar siswa, sikap siswa kurang santun, siswa kurang bekerja sama dalam proses pembelajaran, dan kurang menghargai pendapat yang disampaikan kawan lain. Pada aspek psikomotor siswa tidak mampu menerapkan contoh sikap disiplin di dalam kelas, siswa tidak dapat memberikan penjelasan kepada teman-teman sekelasnya di sekolah tentang pentingnya kedisiplinan diterapkan baik di sekolah, di rumah maupun di tengahtengah kehidupan masyarakat. Dalam upaya meningkat hasil belajar siswa guru di sekolah telah mecoba penggunakan model pembelajaran Konvensional dan Pembelajaran Berbasis Masalah (Problem Based Learning) namun dalam peningkatan hasil belajar siswa belum mendapatkan hasil yang memuaskan.

Melihat permasalahan yang ada, maka salah satu model pembelajaran yang diharapkan mampu untuk mengatasi permasalahan tersebut yaitu menggunakan model pembelajaran TANDUR berbantuan media puzzle. Model pembelajaran TANDUR yaitu suatu rancangan model yang diharapkan dapat sepenuhnya membuat siswa tertarik pada pelajaran, memberikan pengalaman yang langsung kepada siswa dan berusaha menjadikan isi pelajaran nyata bagi mereka (DePotter, et al, 2010: 127).TANDUR sendiri merupakan akronim yang menjadi bagian atau fase-fase pembelajaran, yaitu Tumbuhkan, Alami, Namai, Demonstrasikan, Ulangi, dan Rayakan. Model pembelajaran TANDUR akan memudahkan siswa dalam memahami konsep pembelajaran karena proses pembelajaran diciptakan agar siswa menjadi senang dan nyaman untuk belajar hal ini jelas dapat meningkatkan minat belajar siswa. Kemudian sintak ini memiliki kelebihan dapat menguatkan konsep yang telah dimiliki dengan konsep yang baru.Selain itu dalam penyampaiannya sangat memperhatikan latar belakang karakteristik siswa. Model pembelajaran ini juga berusaha menyingkirkan segala hambatan selama proses pembelajaran berlangsung, sehingga diharapkan dapat menghilangkan rasa bosan siswa dan pada akhirnya siswa merasa senang dan lebih tertarik dalam proses pembelajaran. Hal inilah yang menjadi kelebihan model TANDUR jika dibandingkan dengan model pembelajaran lainnya. 
Puzzle adalah permainan klasik (Syuropati, 2009: 121). Puzzle selalu bisa muncul dengan berbagai gambar menarik dan memiliki banyak manfaat. Puzzle dapat membantu siswa belajar memecahkan masalah dengan mencoba beberapa cara memasangkan kepingan berupa potongan-potongan gambar, maka siswa dilatih untuk berfikir kreatif. Puzzle adalah permainan yang terdiri atas potongan gambar-gambar, kotak-kotak, huruf-huruf atau angka-angka yang disusun seperti dalam sebuah permainan yang akhirnya membentuk sebuah pola tertentu sehingga membuat siswa menjadi termotivasi untuk menyelesaikan puzzle secara tepat dan cepat.

\section{METODE PENELITIAN}

Metode penelitian pada dasarnya merupakan cara ilmiah untuk mendapatkan data dengan tujuan dan kegunaan tertentu (Sugiyono, 2016: 2). Selanjutnya Sugiyono (2016: 9), menyatakan bahwa "Metode kualitatif adalah metode penelitian yang digunakan untuk meneliti kondisi obyek yang alamiah, dimana peneliti ini adalah sebagai intrument kunci, teknik pengumpulan data dilakukan secara trianggulasi (gabungan), analisis data bersifat induktif/kualitatif, dan hasil penelitian kualitatif lebih menekankan makna dari pada generalisasi.

Bentuk penelitian yang digunakan adalah Penelitian Tindakan Kelas (Classroom Action Research). Model penelitian tindakan kelas yang digunakan dalam penelitian ini adalah model Kurt Lewin. Penelitian tindakan kelas model Kurt Lewin memiliki empat tahapan dalam satu siklus, yang terdiri dari perencanaan (planning), pelaksanaan tindakan (acting), pengamatan (observing), dan refleksi (reflecting). Lokasi atau tempat melaksanakan penelitian ini adalah kelas IV SDN 01 Sintang. Sekolah ini terletak di Jl. Apang Semangai,Tanjung Puri, Kecamatan Sintang, Kabupaten Sintang, Kalimantan Barat, Indonesia. Teknik pengumpulan data yang digunakan penelitian tindakan kelas ini adalah teknik observasi, teknik tes, teknik kuesioner tidak langsung, dan teknik dokumentasi. Alat pengumpul data dalam penelitian yaitu Lembar keterlaksanaan pembelajaran, Lembar tes kognitif, Lembar tes afektif yang berbentuk rating scale dengan 4 pilihan, Lembar Tes psikomotor yang berbetuk rating scale dengan 2 pilihan, dan Lembar Respon siswa. Teknik analisis data dalam penelitian ini menggunakan teknik analisis model Miles and Huberman. Miles and Huberman (Sugiyono, 2013: 337), mengemukakan bahwa aktivitas dalam analisis data kualitatif dilakukan secara interaktif dan berlangsung secara terus menerus sampai tuntas. Sehingga datanya sudah jenuh. Aktivitas dalam analisis data, yaitu pengumpulan data, reduksi data, penyajian data dan kesimpulan.

\section{HASIL DAN PEMBAHASAN}

Hasil analisis lembar observasi keterlaksanaan pembelajaran siklus I dan siklus II disajikan pada Tabel 1.

Tabel 1

Hasil Observasi Keterlaksanaan pembelajaran Siklus I dan siklus II

\begin{tabular}{|c|c|c|}
\hline \multirow{2}{*}{ Pertemuar } & \multicolumn{2}{|c|}{ Observasi } \\
\cline { 2 - 3 } & Siklus I & Siklus II \\
\hline I & 66,67 & 90,91 \\
\hline II & 71,43 & 100 \\
\hline rerata & 69,05 & 95,45 \\
\hline
\end{tabular}


Berdasarkan Tabel 1 diperoleh rerata hasil observasi keterlaksanaan pembelajaran siklus I sebesar 69,05dan rerata hasil observasi keterlaksanaan pembelajaran siklus II sebesar 95,45 . Selanjutnya disampaikan hasil belajar ranah afektif siklus I dapat dilihat pada Tabel 2.

Tabel 2

Hasil Belajar Afektif Siswa Siklus I

\begin{tabular}{|c|c|c|c|c|}
\hline \multicolumn{5}{|c|}{ Hasil Tes Afektif } \\
\hline No & Sikap & Skor & $\begin{array}{c}\text { Rata- } \\
\text { rata }\end{array}$ & Kriteria \\
\hline 1 & $\begin{array}{l}\text { Tanggung } \\
\text { Jawab }\end{array}$ & 1.450 & 60,42 & Cukup \\
\hline 2 & $\begin{array}{l}\text { Percaya } \\
\text { Diri }\end{array}$ & 1.475 & 61,46 & Cukup \\
\hline 3 & Kerja Sama & 1.575 & 65,63 & Cukup \\
\hline 4 & Berdo’a & 1.625 & 67,71 & Cukup \\
\hline 5 & Bersyukur & 1.575 & 65,63 & Cukup \\
\hline & Rata-rata & 64,17 & & kup \\
\hline
\end{tabular}

nilai ranah afektif siklus I pada sikap tanggung jawab diperoleh skor 1.450 dengan rata-rata 60,42 dengan kriteria cukup, pada sikap percaya diri diperoleh skor 1.475 dengan ratarata 61,46 dengan kriteria cukup, pada sikap kerja sama diperoleh skor 1.575 dengan ratarata 65,63 dengan kriteria cukup, pada sikap berdo'a diperoleh skor 1.625 dengan rata-rata 67,71 dengan kriteria cukup dan pada sikap bersyukur diproleh skor 1.575 dengan rata-rata 65,63 dengan kriteria cukup. Jadi rerata dari lima sikap yang diamati diperoleh 64,17 yang bearti sikap siswa masih berkriteria cukup.

Hasil nilai ranah psikomotor siswa siklus I dapat dilihat pada Tabel 3.

Tabel 3

Hasil Belajar Psikomotor Siswa Siklus I

\begin{tabular}{ccccc}
\hline \multicolumn{5}{c}{ Hasil Tes Psikomotor } \\
\hline No & \multicolumn{1}{c}{ Aspek } & Skor & ata-rata & Kriteria \\
\hline 1 & Keaktifan & 1.550 & 64,58 & Cukup \\
\hline 2 & $\begin{array}{l}\text { Pengucapatan } \\
\text { kalimat }\end{array}$ & 1.475 & 61,46 & Cukup \\
\hline
\end{tabular}

\begin{tabular}{llll}
\hline 3 & $\begin{array}{l}\text { Keterampilan } \\
\text { membuat } \\
\text { laporan }\end{array}$ & 1.600 & $66,67 \quad$ Cukup \\
\hline Rata-rata & 64,24 & Cukup \\
\hline
\end{tabular}

Berdasarkan Tabel 3 dapat diketahui nilai ranah psikomotor siswa siklus I pada keaktifan diperoleh skor 1.550 dengan rata-rata 64,58 dengan kriteria cukup, pada pengucapan kalimat diperoleh skor 1.475 dengan rata-rata 61,46 dengan kriteria cukup, dan pada keterampilan membuat laporan diperoleh skor 1.600 dengan rata-rata 66,67 dengan kriteria cukup. Jadi jumlah nilai dari tiga aspek yang diamati diperoleh rata-rata 64,24 yang bearti keterampilan siswa masih berkriteria cukup.

Hasil tes kognitif siswa siklus I dapat dilihat pada Tabel 4.

Tabel 4

Hasil Belajar Kognitif Siswa Siklus I

\begin{tabular}{|c|c|c|c|c|}
\hline \multirow{2}{*}{ No } & \multirow{2}{*}{$\begin{array}{l}\text { Hasil Tes } \\
\text { Kognitif }\end{array}$} & \multirow{2}{*}{ Nilai } & \multicolumn{2}{|c|}{ KBK } \\
\hline & & & $\mathrm{L}$ & $\mathrm{TL}$ \\
\hline 1 & $\begin{array}{l}\text { Nilai } \\
\text { Tertinggi }\end{array}$ & 90 & \multirow{3}{*}{$\begin{array}{c}13 \\
\text { Siswa } \\
54,17 \%\end{array}$} & \multirow{3}{*}{$\begin{array}{c}11 \\
\text { Siswa } \\
45,83 \%\end{array}$} \\
\hline 2 & $\begin{array}{l}\text { Nilai } \\
\text { Terendah }\end{array}$ & 50 & & \\
\hline Nila & Rata-rata & 67,91 & & \\
\hline
\end{tabular}

Berdasarkan Tabel 4 dapat diketahui nilai rata-rata dari keseluruhan siswa adalah 67,91 dengan jumlah persentase ketuntasan klasikal 54,17\% berarti belum memenuhi syarat Ketuntasan Belajar Klasikal (KBK) dicapai sekurang-kurangnya $85 \%$ dari jumlah siswa yang memperoleh nilai 70 sesuai dengan KKM yang telah ditetapkan. Dari analisis nilai belajar kognitif siswa setelah selesai tes siklus I bahwa nilai belajar kognitif siswa belum mencapai kriteria ketuntasan klasikal, terdapat 13 siswa yang tuntas dan 11 siswa yang tidak tuntas. 
Hasil belajar siswa yang diperoleh pada siklus I ini menunjukkan hasil yang tidak maksimal, oleh karena itu perlu dilakukan penelitian tindakan kelas pada siklus II.

Hasil nilai ranah afektif siswa siklus II dapat dilihat pada Tabel 5.

Tabel 5

Hasil Belajar Afektif Siswa Siklus II Hasil Tes Afektif

\begin{tabular}{clccc}
\hline No & \multicolumn{1}{c}{ Sikap } & $\begin{array}{c}\text { Skor } \\
\text { Rata- } \\
\text { rata }\end{array}$ & $\begin{array}{c}\text { Kriteri } \\
\text { a }\end{array}$ \\
\hline 1 & Tanggung & $\begin{array}{c}1.82 \\
76,0\end{array}$ & Baik \\
& Jawab & 5 & 4 & \\
\hline 2 & Percaya Diri & $\begin{array}{c}1.57 \\
5\end{array}$ & $\begin{array}{c}65,6 \\
3\end{array}$ & Cukup \\
& & 5 & \\
\hline 3 & Kerja Sama & 1.77 & 73,9 & Baik \\
& & 5 & 6 & \\
\hline 4 & Berdo'a & 1.80 & 75 & Baik \\
& & 0 & & \\
\hline 5 & Bersyukur & 1.77 & 73,9 & Baik \\
& & 5 & 6 & \\
\hline & Rata-rata & 72,9 & \multicolumn{2}{c}{ Baik } \\
& & 2 & \\
\hline
\end{tabular}

Berdasarkan Tabel 5 dapat diketahui nilai ranah afektif siklus II pada sikap tanggung jawab diperoleh skor 1.825 dengan rata-rata 76,04 dengan kriteria baik, pada sikap percaya diri diperoleh skor 1.575 dengan rata-rata 65,63 dengan kriteria cukup, pada sikap kerja sama diperoleh skor 1.775 dengan rata-rata 73,96 dengan kriteria baik, pada sikap berdo'a diperoleh skor 1.800 dengan rata-rata 75 dengan kriteria baik dan pada sikap bersyukur diproleh skor 1.775 dengan rata-rata 73,96 dengan kriteria baik. Jadi jumlah nilai dari lima sikap yang diamati diperoleh skor 8.750 dengan rata-rata 72,92 yang bearti sikap siswa sudah berkriteria baik. Dari analisis penilaian hasil belajar ranah afektif pada siklus II sudah maksimal.
Hasil nilai ranah psikomotor siswa siklus II dapat dilihat pada Tabel 6 .

Tabel 6

Hasil Belajar Psikomotor Siswa Siklus II

\begin{tabular}{llccc}
\hline \multicolumn{5}{c}{ Hasil Tes Psikomotor } \\
\hline No & \multicolumn{1}{c}{ Aspek } & Skor & $\begin{array}{c}\text { Rata- } \\
\text { rata }\end{array}$ & Kriteria \\
\hline 1 & Keaktifan & 1.725 & 71,88 & Baik \\
\hline 2 & $\begin{array}{l}\text { Pengucapan } \\
\text { kalimat }\end{array}$ & 1.600 & 66,67 & Cukup \\
\hline 3 & $\begin{array}{l}\text { Keterampilan } \\
\text { membuat } \\
\text { laporan tertulis }\end{array}$ & 2.000 & 83,33 & $\begin{array}{c}\text { Sangat } \\
\text { Baik }\end{array}$ \\
\hline & Rata-rata & 73,96 & Baik \\
\hline
\end{tabular}

Berdasarkan hasil Tabel 6 dapat diketahui nilai ranah psikomotor siswa siklus II pada keaktifan diperoleh skor 1.725 dengan rata-rata 71,88 dengan kriteria baik, pada pengucapan kalimat diperoleh skor 1.600 dengan rata-rata 66,67 dengan kriteria cukup, dan pada keterampilan membuat laporan tertulis diperoleh skor 2.000 dengan rata-rata 83,33 dengan kriteria sangat baik. Jadi jumlah nilai dari tiga aspek yang diamati diperoleh skor 5.325 dengan rata-rata 73,96 yang bearti keterampilan siswa masih berkriteria baik. Dari analisis penilaian hasil belajar ranah psikomotor pada siklus II sudah maksimal.

Hasil tes kognitif siswa siklus II dapat dilihat pada Tabel 7 .

Tabel 7

Hasil Belajar Kognitif Siswa Siklus II

\begin{tabular}{|c|c|c|c|c|}
\hline \multirow{2}{*}{ No } & \multirow{2}{*}{$\begin{array}{c}\text { Hasil } \\
\text { Tes } \\
\text { Kognitif }\end{array}$} & \multirow{2}{*}{ Nilai } & \multicolumn{2}{|c|}{ KBK } \\
\hline & & & $\mathrm{L}$ & TL \\
\hline 1 & $\begin{array}{l}\text { Nilai } \\
\text { Tertinggi }\end{array}$ & 100 & \multirow{3}{*}{$\begin{array}{c}21 \\
\text { Siswa } \\
87,5 \%\end{array}$} & \multirow{3}{*}{$\begin{array}{c}3 \\
\text { Siswa } \\
12,5 \%\end{array}$} \\
\hline 2 & $\begin{array}{l}\text { Nilai } \\
\text { Terendah }\end{array}$ & 65 & & \\
\hline Nila & Rata-rata & 81,04 & & \\
\hline
\end{tabular}

Berdasarkan Tabel 7 dapat diketahui nilai rata-rata dari keseluruhan siswa adalah 
81,04 dengan KBK sebesar 87,5\% berarti sudah memenuhi syarat ketuntasan belajar klasikal dicapai sekurang-kurangnya $85 \%$ dari jumlah siswa yang memperoleh nilai 70 sesuai dengan KKM yang telah ditetapkan. Dari analisis nilai belajar kognitif siswa setelah selesai tes siklus II bahwa nilai belajar kognitif siswa sudah mencapai kriteria ketuntasan klasikal, terdapat 21 siswa yang tuntas dan 3 siswa yang tidak tuntas.

Berdasarkan hasil data yang sudah dipaparkan di atas dapat disimpulkan bahwa pada siklus II telah menunjukan perubahan yang baik, maka peneliti memutuskan untuk behenti pada siklus II, karena ketuntasan belajar yang diharapkan sudah mencapai kriteria yang diharapkan.

Berdasarkan pelaksanaan penelitian di lapangan, hasil observasi penerapan model pembelajaran TANDUR berbantuan media puzzle pada tema indahnya keragaman di ngeriku di kelas IV SD Negeri 01 Sintang Tahun Pelajaran 2019/2020 dapat dikatakan berjalan dengan baik dan model pembelajaran TANDUR berbantuan media puzzle dapat diterapkan. Hal tersebut dapat dilihat dari peningkatan observasi aktivitas guru dan siswa pada siklus I ke siklus II, bahwa siswa mampu mengikuti proses pembelajaran dengan baik sesuai dengan langkah-langkah dalam model pembelajaran dengan antusias dan baik sehingga hasil belajar siswa juga meningkat.

Berdasarkan hasil observasi aktivitas guru pada siklus I dengan rata-rata persentase sebesar $69,05 \%$ termasuk kriteria cukup, sedangkan hasil observasi aktivitas guru pada siklus II dengan rata-rata persentase sebesar
95,46\% termasuk kriteria sangat baik. Hasil observasi aktivitas siswa pada siklus I dengan rata-rata persentase sebesar $61,91 \%$ termasuk kriteria cukup, sedangkan hasil observasi aktivitas siswa pada siklus II dengan rata-rata persentase sebesar 93,18\% termasuk kriteria sangat baik. Hal ini berarti hasil observasi aktivitas guru dan siswa sudah mencapai tingkat maksimal sehingga berpengaruh pada peningkatan hasil belajar siswa. Hasil penelitian ini sejalan dengan penelitian yang dilakukan oleh Kolang, dkk. (2013), menyatakan bahwa "Peningkatan aktivitas siswa ini disebabkan karena aktivitas guru yang semakin baik dalam proses pembelajaran, seperti guru terus berusaha memberikan motivasi dan bimbingan kepada siswa agar siswa berminat dan aktif dalam mengikuti proses belajar mengajar, guru terus berusaha menanamkan rasa percaya diri di dalam diri siswa.

Hasil belajar siswa setelah menggunakan model pembelajaran TANDUR berbantuan media puzzle pada tema indahnya keragaman di negeriku di kelas IV SD Negeri 01 Sintang Tahun Pembelajaran 2019/2020 dikatakan lulus, dari hasil yang telah dikumpulkan, pada ranah kognitif dengan nilai rata-rata siklus I sebesar 67,91 dengan kategori tidak lulus, sedangkan pada siklus II mengalami peningkatan yang signifikan menjadi 81,04. Pada ranah afektif nilai rata-rata siklus I sebesar 64,17 dengan kategori cukup, sedangkan pada siklus II mengalami peningkatan sebesar 72,92 dengan kategori baik. Pada ranah psikomotor nilai rata-rata siklus I sebesar 64,24 dengan kategori cukup, sedangkan pada siklus II 
mengalami peningkatan sebesar 73,96 dengan kategori baik.

Hasil penelitian ini sejalan dengan hasil penelitian Suriani (2019), menyatakan bahwa "Model pembelajaran TANDUR dalam kegiatan pembelajaran dapat meningkatkan hasil belajar siswa". Penilitian ini juga sejalan dengan hasil penelitian Koolang, dkk. (2013), menyatakan bahwa "Dengan digunakan model pembelajaran TANDUR, siswa lebih antusias dan senang dalam belajar, karena mereka dapat mengeluarkan pendapat/argumentasinya sehingga timbul rasa percaya diri dan tidak merasa takut serta malu dalam mengungkapkan hasil diskusi.

Hasil belajar dengan menggunakan model pembelajaran TANDUR berbantuan media puzzle pada tema tema indahnya keragaman di negeriku di kelas IV SD Negeri 01 Sintang Tahun Pelajaran 2019/2020 dapat dikatakan baik dan mengalami peningkatan. Hal ini dapat dilihat pada penjelasan berikut.

a. Peningkatan Hasil Belajar Kognitif Siswa

Nilai ranah kognitif siswa dengan menggunakan model pembelajaran TANDUR berbantuan media puzzle pada tema indahnya keragaman di negeriku dapat dikatakan baik dan mengalami peningktan. Peningkatan hasil belajar kognitif siswa siklus I ke siklus II dapat dilihat berdasarkan ketuntasan klasikal belajar kognitif siswa mulai dari siklus I sampai siklus II mengalami peningkatan. Pada siklus I ketuntasan klasikal belajar kognitif siswa adalah $54,17 \%$ dan pada siklus II mengalami peningkatan yang signifikan menjadi $87,5 \%$ sehingga mengalami peningkatan sebesar 33,33\%. Berarti, penilaian tindakan yang dilakukan terhadap peningkatan hasil belajar kognitif siswa dengan menggunakan model pembelajaran TANDUR berbantuan media puzzle pada tema indahnya keragaman di negeriku di kelas IV SD Negeri 01 Sintang Tahun Pelajaran 2019/2020 berhasil dan berjalan dengan baik. Hasil penelitian ini sejalan dengan hasil penelitian Suriani (2019), menyatakan bahwa "Model pembelajaran TANDUR dalam kegiatan pembelajaran dapat meningkatkan hasil belajar siswa". Penilitian ini juga sejalan dengan hasil penelitian Koolang, dkk. (2013), menyatakan bahwa "Dengan digunakan model pembelajaran TANDUR, siswa lebih antusias dan senang dalam belajar, karena mereka dapat mengeluarkan pendapat/argumentasinya sehingga timbul rasa percaya diri dan tidak merasa takut serta malu dalam mengungkapkan hasil diskusi.

b. Peningkatan Hasil Belajar Afektif Siswa

Hasil belajar ranah afektif siswa dengan menggunakan model pembelajaran TANDUR berbantuan media puzzle pada tema indahnya keragaman di negeriku dapat dikatakan baik dan mengalami peningkatan. Hal ini dapat dilihat dari persentase rata-rata nilai belajar ranah afektif siswa yang dicapai pada nilai belajar siswa berdasarkan aspek sikap yang diamati.Peningkatan hasil belajar afektif siswa siklus I ke siklus II dapat dilihat nilai rata-rata ranah afektif siswa mulai dari siklus I ke siklus II mengalami peningkatan. Pada siklus I nilai rata-rata ranah afektif sebesar $64,17 \%$ 
termasuk kriteria cukup dan pada siklus II mengalami peningkatan menjadi $72,92 \%$ termasuk kriteria baik, sehingga mengalami peningkatan sebesar 8,75\%. Berarti, penilaian tindakan yang dilakukan terhadap peningkatan hasil belajar afektif siswa dengan menggunakan model pembelajaran TANDUR berbantuan media puzzle pada tema indahnya keragaman di negeriku di kelas IV SD Negeri 01 Sintang Tahun Pelajaran 2019/2020 berhasil dan hampir berjalan dengan maksimal.

Siswa yang bersikap positif selama proses pembelajaran akan menyenangi materi pelajaran dan proses pembelajaran tersebut. Hal ini sesuai dengan penelitian Sakaningsih (2018: 132) yang menyatakan, "Pembelajaran quantum menekankan kegiatan pada pengembangan potensi manusia secara optimal melalui cara-cara yang sangat manusiawi yaitu mudah, menyenangkan dan memberdayakan." Pada kurikulum 2013, ranah afektif tidak terlepas dari analisis tingkah laku yang dipelajari dan keadaan tingkah laku belajar siswa. Siswa dalam proses pembelajaran perlu menguasai tingkah lakunya, tingkah lakunya setelah mengikuti kegiatan pembelajaran.

c. Peningkatan Hasil Belajar Psikomotor Siswa

Nilai hasil belajar ranah psikomotor siswa dengan menggunakan model pembelajaran TANDUR berbantuan media puzzle pada tema indahnya keragaman di negeriku dapat dikatakan baik dan mengalami peningkatan. Hal ini dapat dilihat dari persentase rata-rata nilai belajar ranah psikomotor siswa yang dicapai pada nilai belajar siswa berdasarkan aspek keterampilan yang diamati.Peningkatan hasil belajar psikomotor siswa siklus I ke siklus II dapat dilihat nilai rata-rata ranah psikomotor siswa mulai dari siklus I ke siklus II mengalami peningkatan. Pada siklus I nilai rata-rata ranah psikomotor sebesar $64,24 \%$ termasuk kriteria cukup dan pada siklus II mengalami peningkatan menjadi $73,96 \%$ termasuk kriteria baik, sehingga mengalami peningkatan sebesar 9,72\%. Berarti, penilaian tindakan yang dilakukan terhadap peningkatan hasil belajar psikomotor siswa dengan menggunakan model pembelajaran TANDUR berbantuan media puzzle pada tema indahnya keragaman di negeriku di kelas IV SD Negeri 01 Sintang Tahun Pelajaran 2019/2020 berhasil dan berjalan dengan maksimal.

Hasil penelitian ini sesuai dengan pendapat Mulyasa seperti dikutip Wibowo (2016: 130), yang menjelaskan bahwa "pembelajaran dikatakan berhasil dan berkualitas apabila seluruhnya atau setidaktidaknya sebagian besar peserta didik terlibat secara aktif, baik fisik, mental maupun sosial dalam proses pembelajaran". Berdasarkan pelaksaan tersebut, keaktifan siswa dalam mengikuti proses belajar mengajar akan meningkat. Peningkatan ini terlihat dari hasil yang diperoleh pada siklus pembelajaran.Suasana belajar yang menyenangkan membuat siswa lebih mudah memahami materi. 
Berdasarkan hasil angket yang diberikan kepada siswa untuk mengetahui respon siswa serta memperkuat hasil penelitian terhadap penggunaan model pembelajaran TANDUR berbantuan media puzzle pada tema indahnya keragaman di negeriku mendapat respon sangat baik. Berdasarkan hasil analisis data diperoleh persentase total sebesar 89,56\%dengan kategori sangat baik atau penggunaa model pembelajaran TANDUR berbantuan media puzzle pada tema indahnya keragaman di negeriku mendapat respon sangat baik untuk membantu siswa dalam meningkatkan hasil belajar. Respon siswa yang sangat baik ini dikarenakan model pembelajaran TANDUR berbantuan media puzzle merupakan media pembelajaran yang memberikan motivasi bagi siswa dan sangat menarik terutama pada tema indahnya keragaman di negeriku, sehingga sangat cocok untuk meningkatkan hasil belajar siswa. Model pembelajaran TANDUR berbantuan media puzzle membantu guru dalam menyampaikan informasi dan siswa dapat dengan leluasa mengekspresikan gagasan secara terbuka sehingga konsep pembelajaran menarik dan interaktif dapat tercipta dalam proses ini.

\section{SIMPULAN}

Berdasarkan analisis data yang dilakukan dalam penelitian, maka secara umum dapat ditarik kesimpulan bahwa model pembelajaran TANDUR berbantuan media puzzle dapat digunakan untuk meningkatkan hasil belajar siswa pada tema indahnya keragaman di negeriku di kelas IV SD Negeri 01 Sintang Tahun Pelajaran 2019/2020. Berdasarkan submasalah yang ada, maka dapat ditarik kesimpulan sebagai berikut.

1. Penerapan model pembelajaran TANDUR berbantuan media puzzle pada tema indahnya keragaman di negeriku di kelas IV SD Negeri 01 Sintang Tahun Pembelajaran 2019/2020 sangat baik, dari hasil observasi aktivitas guru dan aktivitas siswa yang telah dikumpulkan dengan dua kali pertemuan pada siklus kedua dengan persentase total kedua pertemuan oleh seorang observer yaitu aktivitas guru yaitu 95,46\% dengan kriteria sangat baik dan aktivitas siswa yaitu 93,18\% dengan kriteria sangat baik.

2. Hasil belajar siswa setelah menggunakan model pembelajaran TANDUR berbantuan media puzzle pada tema indahnya keragaman di negeriku di kelas IV SD Negeri 01 Sintang Tahun Pembelajaran 2019/2020 dikatakan lulus, dari hasil yang telah dikumpulkan, pada ranah kognitif dengan nilai rata-rata siklus I sebesar 67,91 dengan kategori tidak lulus, sedangkan pada siklus II mengalami peningkatan yang signifikan menjadi 81,04. Pada ranah afektif nilai rata-rata siklus I sebesar 64,17 dengan kategori cukup, sedangkan pada siklus II mengalami peningkatan sebesar 72,92 dengan kategori baik. Pada ranah psikomotor nilai rata-rata siklus I sebesar 64,24 dengan kategori cukup, sedangkan pada siklus II mengalami peningkatan sebesar 73,96 dengan kategori baik.

3. Peningkatan hasil belajar siswa dengan model pembelajaran TANDUR berbantuan media puzzle pada tema indahnya keragaman di negeriku di kelas IV SD 
Negeri 01 Sintang Tahun Pembelajaran 2019/2020 yakni mengalami peningkatan. Peningkatan klasikal pada ranah kognitif sebesar 33,33\%, hal ini terlihat pada siklus I memperoleh nilai sebesar $54,17 \%$ dan pada siklus II sebesar $87,5 \%$. Peningkatan pada ranah afektif sebesar $8,75 \%$, hal ini terlihat pada siklus I memperoleh nilai sebesar 64,17\% dengan kriteria cukup dan pada siklus II memperoleh nilai sebesar 72,92\% dengan kriteria baik. Peningkatan pada ranah psikomotor sebesar 9,72\%, hal ini terlihat pada siklus I memperoleh nilai sebesar 64,24\% dengan kriteria cukup dan pada siklus II memperoleh nilai sebesar $73,96 \%$ dengan kriteria baik.

\section{DAFTAR RUJUKAN}

Anderson, L. W dan Krathwohl, D. R. 2001.A Taxonomy for Learning, Teaching, and Assesing: A Revision of Bloom's Taxonomy of Educatioanl Objectives. New York: Addison Wesley Longman, Inc.

Awang, I. S. 2017. Strategi Pembelajaran, Tinjauan Umum Bagi Pendidik. Sintang: STKIP Persada Khatulistiwa.

Baharuddin. 2004. Paradigma Psikologi Islami. Yogyakarta: Pustaka Pelajar.

DePotter, B. et al. 2010. Quantum Teaching: Mempraktikkan Quantum Learning di Ruang-Ruang Kelas. Terjemahan Ary Nilandari.Quantum Teaching: Orchestrating Student Success. Bandung: Kaifa.

Koolang, S. M. Rede, A. Jamhari, M. 2013. "Meningkatkan Hasil Belajar Siswa Pada Materi Berbagi Peristiwa Alam Di Kelas V SDN Pakanangi Melalui Model Pembelajaran Quantum Teaching".
Jurnal Kreatif Tadulako. Volume 1 Nomor 2.

Nurbudiyani, I. 2013. "Pelaksanaan Pengukuran Ranah Kognitif, Afektif, Dan Psikomotor Pada Mata Pelajaran IPS Kelas III SD Muhammadiyah Palangkaraya". Anterior Jurnal. Volume 13 Nomor 1 Hal 88 - 93.

Pribadi, A. B. 2014. Desain dan Pengembangan Program Pelatihan Berbasis Kompetensi: Implementasi Model Addie. Jakarta: Kencana.

Sakaningsih, N.M., Margunayasa, I.G. 2018. Penerapan Model Pembelajaran Quantum Berbantuan Media AudioVisual dan Puzzle Untuk Meningkatkan Hasil Belajar PPKN. Jurnal Ilmiah Pendidikan Profesi Guru, 1(2) 124-133.

Sugiyono. 2013a.Metode Penelitian Kuantitatif, Kualitatif, dan $R \& D$. Bandung: Alfabeta.

Sugiyono. 2016a.Metode Penelitian Kuantitatif, Kualitatif, dan $R \& D$. Bandung: Alfabeta.

Sugiyono. 2016b.Metode Penelitian Kuantitatif, Kualitatif, dan $R \& D$. Bandung: Alfabeta.

Sukardi. 2009. Evaluasi Pendidikan: Prinsip Operasinal. Jakarta: Bumi Aksara.

Suriani, D. 2019. "Upaya Meningkatkan Hasil Belajar Siswa Pada Mata Pelajaran IPA Materi Metamorfosis Melalui Model Quantum Teaching Kelas IV Min Sei Mati KecamatanMedan Labuhan Tahun Pelajaran 2018/2019". Skripsi. Medan: Universitas Islam Negeri Sumatera Utara.

Susanto, A. 2013.Teori Belajar dan Pembelajaran di Sekolah Dasar. Jakarta: Kencana Prenada Media Group.

Syuropati, M. 2009. Inspirasi Anak Anda dengan Permainan yang Mencerdaskan. Bantul: In Azna Books. 
Wibowo, N. 2016.Upaya Peningkatan

Keaktifan Siswa Melalui Pembelajaran Berdasarkan Gaya Belajar Di Smk Negeri 1 Saptosari. Jurnal Electronics, Informatics, and Vocational Education (ELINVO), 1(2)128-139. 